\title{
Floristic Composition of Selected Lowland Meadows in the Liw Commune
}

\author{
Jacek Sosnowski ${ }^{1 *}$, Krzysztof Marek Solka' \\ 1 Department of Grassland and Green Areas Creation, Siedlce University of Natural Sciences and Humanities, \\ ul. Prusa 14, 08-110 Siedlce, Poland \\ * Corresponding author's e-mail: jacek.sosnowski@uph.edu.pl
}

\begin{abstract}
The aim of this paper was to assess the vegetation of six lowland meadows, or study units, located in the Liw Commune. In order to meet the objectives of the research, a detailed list of species on the meadows was drawn up and a weighing analysis of vegetation in individual harvest was carried out. The research involving six meadows was carried out during the 2016 growing season. The meadows were situated in two villages: Ruchna and Ruchenka, located in the Masovian Voivodeship, Węgrów County, and the Liw Commune. The meadows under consideration occupy a total of 19 hectares. They comprise brown soil, leached and acidic, consisting of light clay, with a lower layer of heavy clay and black soil proper of very good quality, made up of light clay lying on medium clay. The soil of the meadows had a high and very high content of mineral nitrogen and magnesium, low or medium content of phosphorus, and a very low content of potassium. Three of the analyzed meadows were harvested three times, while the others were harvested four times. The results of the weighing analysis of the meadows were very varied, both between the units and between harvests. However, it should be noted that in all units the grass share, as an average of all harvest, was in majority of cases, in the range from $55 \%$ to $62 \%$.
\end{abstract}

Keywords: plants, weed, herb, forage value index, Poaceae, Fabaceae

\section{INTRODUCTION}

The meadow vegetation is composed of many different plant species, including grasses, Fabaceae, Juncaceae, Cyperaceae, herbs and weeds. Individual species differ from each other in terms of their nutritional value and habitat requirements. Apart from the species of high value, improving the nutritional quality of the forage, there are also low-value or harmful plants, which are undesirable in a meadow. This in particular includes such species as meadowsweet Filipendula ulmaria and Geum nutans, negatively affecting the soil, or marsh marigold Caltha palustris and Ranunculus, weeds lowering the forage value and, in effect, the value of animal products. Therefore, it is important to analyze the composition of meadow vegetation by identifying the plant species (Czyż et al., 2015). The analysis of plant communities, with sufficient and substantive interpretation, will provide knowledge on the forage biomass value and on the possible ways of grassland regeneration. Permanent grassland vegetation also reflects the habitat preferences of plant communities. The knowledge on species composition helps determining the necessary pratotechnic treatments in the context of harvest frequency, fertilizer use, or draining system. Studies indicate (Rychnovska et al., 1994) that the meadow ecosystems in Poland have a wealth of flora and fauna. Approximately 350 plant species can be found on grasslands, out of which the grass species constitute $15 \%, \mathrm{Fa}$ baceae 5\%, while other herbaceous species from virtually all families form the remaining $80 \%$. Such multiple species composition enables to fully exploit the habitats of meadows and pastures. Individual species created a variety of ecotypes, specifically adapted to the habitat conditions, as well as to the methods of grassland use. It is a proof of the flexibility of those communities in 
maintaining the biocenosis balance. Additionally, such a large number of ecotypes create a unique gene bank which allows growing new varieties of agricultural plants (Nazaruk, 1995; Goliński, 1999; Jankowski et al., 2005; Baryła and Kulik, 2006; Kulik and Baryła, 2013).

The aim of this paper was to assess the vegetation of six lowland meadows, or study units, located in the Liw Commune. In order to meet the objectives of the research, a detailed list of species on the meadows was drawn up and a weighing analysis of vegetation in individual harvest was carried out.

\section{MATERIAL AND METHODS}

\section{Location of the meadows}

The research involving six meadows was carried out during the 2016 growing season. The meadows were situated in two villages: Ruchna and Ruchenka, located in the Masovian Voivodeship, Węgrów County, and the Liw Commune $\left(52^{\circ} 10^{\prime} 03^{\prime \prime} \mathrm{N} ; 22^{\circ} 17^{\prime} 24^{\prime \prime} \mathrm{E}\right.$; Poland). The Commune is located in the central and eastern part of the County and borders with almost all of its other communes: Miedzna and Stoczek in the north, Korytnica and Wierzbno in the west, and Grębków and Mokobody (Siedlce County); in the south, with the communes of Bielany and Sokołów Podlaski in the east, the last two in the Sokołów Podlaski County. The Liw Commune almost entirely surrounds the town of Węgrów, constituting $13.9 \%$ of its surface area. The Commune covers $169.56 \mathrm{~km}^{2}$, out of which $71 \%$ is agricultural land and $22 \%$ is forest land. One of the meadows is located in the village of Ruchna, and the remaining five are in the neighbouring village of Ruchenka. Both villages are located in the eastern part of the Live Commune. Meadows and permanent pastures occupy an area of about 19 ha.

\section{Analysis of the vegetation}

A list of individual plant species was made by observing the meadows in spring. On the basis of these observations, a list of species of $\mathrm{Poa}$ ceae and Fabaceae families as well as herbs and weeds in each meadow was drawn up. In turn, the qualitative evaluation of the vegetation was made on the basis of the Stebler-Schröter weighing method after each harvest. The plant material was collected after each harvest, with 10 samples from each meadow. The sample size was $1000 \mathrm{~g}$ of plant fresh matter. Then, the samples were divided into three groups: grass, Fabaceae, and herbs and weeds. After the separation, each group of plants was weighed and its percentage in the whole sample was calculated.

\section{The characteristics of soil fertility and types}

The first study unit, a meadow in the village of Ruchna, was located on fertile land, which was good quality brown soil, class IIIa (according to the Polish classification system), leached and acidic, of good quality wheat complex and composed of clay loam with a layer of sandy clay loam below. A small part of the outer areas of the meadow is black soil proper of very good quality wheat complex, consisting of light clay on clay loam. The other five meadows were located in the village of Ruchenka, with the second study unit located on the land of very good quality, i.e. class IIIa, with a small area of class IIIb, which was, for the most part, black proper soil of very good quality wheat complex. It was made up of sandy clay loam with clay loam below it. A small part of that meadow was leached and acidic brown soil, of good quality wheat complex, made up of light clay. Meadow 3 was located on good and medium quality soil classes IIIa, IIIb, and IVa. The largest part of the meadow was brown soil, leached and acidic, consisting of light clay with a narrow lower layer of heavy clay. One part of the meadow was of good quality wheat complex and the other was moderately fertile but heavy. A small portion of the meadow is black proper soil, alluvial and of good quality wheat complex, with sandy clay loam on medium clay. Black soil of very good quality wheat complex and made of light clay loam with a lower layer of medium clay covers the edges of the meadow. Meadow 4 was also located on fertile and moderately fertile soil of classes IIIa, IIIb, and IVa. It is brown soil, leached and acidic, made of up of light clay with heavy clay under it. An equal part of the meadow was black soil of very good quality wheat complex, comprising light clay with medium clay underneath. A small portion was black soil proper, alluvial and of good quality wheat complex, made up of fertile sandy clay loam, with a lower layer of medium clay. Meadow 5 was on fertile and moderately fertile soil of classes IIIb and IVa. It was located on degraded black soil and gray soil 
of very good quality wheat complex. The soil was made up of light clay with a lower layer of heavy clay. A small part of the meadow was fertile brown soil, leached and acidic, comprising sandy clay loam, with medium clay underneath. A small part of the outer edges was brown soil, leached and acidic, of good quality wheat complex and made up of heavy sandy loam with medium clay underneath. Meadow 6, with a homestead on its area, was located on very fertile soil of classes IIIa and IIIb. A little over half of the area was brown soil, leached and acidic, of good quality wheat complex and made up of light clay. The remainder of the soil was black proper soil of very good quality wheat complex. It consisted of light clay with a lower layer of medium clay. A 5-degree scale was used to rate the mineral content: very low, low, medium, high, and very high. The average content of available phosphorus $\left(\mathrm{P}_{2} \mathrm{O}_{5}\right)$ in the soil of the meadows was $8.2 \mathrm{mg}$ per $100 \mathrm{~g}$ soil, which is low. On meadows 1 and 3, the average content was 11.2 and $10.9 \mathrm{mg}$ per $100 \mathrm{~g}$ soil, respectively. On meadow 6 , it was $9 \mathrm{mg} \cdot 100 \mathrm{~g}^{-1}$ soil, which was close to medium. On meadows 2, 4 and 5, the $\mathrm{P}_{2} \mathrm{O}_{5}$ content was low or very low, which means that phosphorus fertilizer was needed there to increase the yield.

The average soil content of the available potassium in the form of $\mathrm{K}_{2} \mathrm{O}$ was very low, with $6.45 \mathrm{mg}$ per $100 \mathrm{~g}$ soil. In no case did it reach $15 \mathrm{mg}$ per $100 \mathrm{~g}$ soil, which is the lowest acceptable level. This means that the meadows should be fertilized with potassium more intensely than before. In autumn, potassium was provided at the amount of $60 \mathrm{~kg} \cdot \mathrm{ha}^{-1}$ of $\mathrm{K}_{2} \mathrm{O}$ to all study units, and in the early spring the dose was $120 \mathrm{~kg} \cdot \mathrm{ha}^{-1}$ of $\mathrm{K}_{2} \mathrm{O}$. Additionally, after the first harvest, 48 $\mathrm{kg} \cdot \mathrm{ha}^{-1}$ of $\mathrm{K}_{2} \mathrm{O}$ was applied to meadows $1,2,3$, 4 , and 5, while unit 6 was treated with $72 \mathrm{~kg} \cdot \mathrm{ha}^{-1}$ $\mathrm{K}_{2} \mathrm{O}$. On all meadows, the content of available magnesium $(\mathrm{Mg})$ in the soil was very high, with an average of $14.57 \mathrm{mg}$ per $100 \mathrm{~g}$ soil. The highest value was recorded in meadow 3 , where there was $19.4 \mathrm{mg}$ per $100 \mathrm{~g}$ soil, and the lowest was in unit 1, with $10.3 \mathrm{mg}$ per $100 \mathrm{~g}$ soil. Magnesium infiltrates into the soil together with calcium fertilization. The primary factor determining the availability of soil nutrients is its proper $\mathrm{pH}$. For mineral soils, the optimal $\mathrm{pH}$ in $\mathrm{KCl}$ should range from 5.0 to 6.0. The grass species are tolerant of a broad range of $\mathrm{pH}$. They thrive in acidic and neutral soils, but Fabeacea plants are more sensitive to low $\mathrm{pH}$ where they grow slowly or die out.
On average, the $\mathrm{pH}$ in $\mathrm{KCl}$ in the meadow soil was 6.42 . In meadows $1,3,4,5$, and 6 the soil was slightly acidic, with $\mathrm{pH}$ ranging from 6.1 to 6.5. In meadow 2, $\mathrm{pH}$ in $\mathrm{KCl}$ was neutral, at 6.9. Liming in the last case was unnecessary, but on the other units it was necessary in order to maintain proper $\mathrm{pH}$, which, at the same time, provided favourable conditions for adequate soil structure and correct assimilation of nutrients, increasing the soil nitrogen availability and assuring greater yields of crops. On the meadows, the last liming was carried out in 2014. It was applied at a dose ranging from about 1.5 to $2 \mathrm{t}^{-} \mathrm{ha}^{-1}$ of $\mathrm{CaO}$. For the last 10 years $\mathrm{CaO}$ had been applied systematically every 3-4 years, with liming of the grassland and arable land bringing about very beneficial effects.

In autumn, determination of mineral nitrogen in the soil $\left(\mathrm{N}_{\min }\right)$ for the sum of layers from 0 to $60 \mathrm{~cm}$ was carried out. This procedure has a 5 degree scale: very low, low, medium, high, and very high. In the meadows, the average nitrogen content $\left(\mathrm{N}_{\min }\right)$ in the 0 to $60 \mathrm{~cm}$ soil layer was $99.33 \mathrm{~kg} \cdot \mathrm{ha}^{-1}$, which can be considered very high. In the study units 1 and 4 it was assessed as average, with 86 and $82 \mathrm{~kg} \cdot \mathrm{ha}^{-1}$, respectively. In those meadows, nitrogen fertilization should be left at its current level. In meadow 5, the content of $\mathrm{N}_{\min }$ was high, but with $88 \mathrm{~kg} \cdot \mathrm{ha}^{-1}$ it was close to medium, so nitrogen fertilization should not be reduced. Meadows 2, 3, and 6 had a very high content of $\mathrm{N}_{\text {min }}$, with 118,117 , and $105 \mathrm{~kg} \cdot \mathrm{ha}^{-1}$, respectively. In this case, the nitrogen fertilization can be reduced by the difference between the actual content of $\mathrm{N}_{\min }$ in the soil and its required content. The nitrogen in soil comes from precipitation, from the activities of free-living nitrogenfixing micro-organisms, as well as from from the bacteria living in symbiosis with Fabeceae plants, but the main source is mineral and organic fertilizers as well as decaying plants and animals.

\section{Fertilizers applied}

At the beginning of spring, nitrogen was applied to meadows in different forms. As early as on 25.03.2016 it was added to the soil together with phosphorous and potassium in Polifoska 6, in a quantity of $400 \mathrm{~kg} \cdot \mathrm{ha}^{-1}$, which was $24 \mathrm{~kg} \cdot \mathrm{ha}^{-1}$ $\mathrm{NH}_{4}^{+}$. Then, 4.04.2016 the nitrogen in the form of $28.5 \mathrm{~kg} \cdot \mathrm{ha}^{-1} \mathrm{NH}_{4}^{+}$and $10.5 \mathrm{~kg} \cdot \mathrm{ha}^{-1} \mathrm{NO}_{3}^{-}$was applied together with sulphur, as Saletrosan 26, in an amount of $150 \mathrm{~kg} \cdot \mathrm{ha}^{-1}$. On 19.04.2016, $180 \mathrm{~kg} \cdot \mathrm{ha}^{-1}$ of urea was applied, with nitrogen 
in the amide form $\left(\mathrm{C}-\mathrm{NH}_{2}\right)$, which was $82.8 \mathrm{~kg}$ $\mathrm{N} \cdot \mathrm{ha}^{-1}$. The fertilizer used finally, on 2.05.2016, was Puławska ammonium nitrate in an amount of $200 \mathrm{~kg} \cdot \mathrm{ha}^{-1}$, when the soil was enriched with $34 \mathrm{~kg} \cdot \mathrm{ha}^{-1} \mathrm{NH}_{4}^{+}$and $34 \mathrm{~kg} \cdot \mathrm{ha}^{-1} \mathrm{NO}_{3}^{-}$. After each harvest, the Puławska ammonium nitrate was applied in amounts of $200 \mathrm{~kg}$ - ha- 1 on 25.05 .2016 , $160 \mathrm{~kg} \cdot \mathrm{ha}^{-1}$ on 4.07 .2016 , and $100 \mathrm{~kg} \cdot \mathrm{ha}^{-1}$ on 25.08.2016. Totally, the soil was fertilized with $78.2 \mathrm{~kg} \cdot \mathrm{ha}^{-1}$ of $\mathrm{NH}_{4}^{+}$and $78.2 \mathrm{~kg} \cdot \mathrm{ha}^{-1}$ of $\mathrm{NO}_{3}^{-}$. Summing up, all nitrogen fertilizer doses in the growing period amounted to $370.2 \mathrm{~kg} \cdot \mathrm{ha}^{-1}$.

\section{Meteorological conditions}

The meteorological data of 2016 were obtained from the Hydrological-Meteorological Station in Siedlce. The average air temperature during the experiment was very similar to the long-term average temperature (Table 1). The highest average monthly temperature was in July $\left(19^{\circ} \mathrm{C}\right)$ and August $\left(17.9^{\circ} \mathrm{C}\right)$, while the lowest was during the months of April $\left(8.9^{\circ} \mathrm{C}\right)$ and October $\left(6.8^{\circ} \mathrm{C}\right)$. In the growing period of 2016 the months with the highest precipitation were July $(126.8 \mathrm{~mm})$ and October $(161.2 \mathrm{~mm})$. The lowest rainfall was recorded in September $(15.4 \mathrm{~mm})$ and May $(35.5 \mathrm{~mm})$.

In order to study the temporal variation of the meteorological conditions and their effects on plant growth, Selianinov's hydrothermal coefficient was determined (Skowera and Puła, 2004). The coefficient was calculated on the basis of the monthly sums of precipitation (P) and the monthly total air temperature ( $\mathrm{t}$ ), using the following formula (Skowera and Puła, 2004):

$$
\mathrm{K}=\mathrm{P} / 0,1 \sum \mathrm{t}
$$

In assessing the hydrothermal conditions, the following ranges of Selianinov's hydrothermal coefficient values (K), according to Skowera and Puła (2004), were used:
$\mathrm{K} \leq 0.4$ extremely dry (ss),
$0.4<\mathrm{K} \leq 0.7$ very dry (bs),
$0.7<\mathrm{K} \leq 1.0$ dry (s),
$1.0<\mathrm{K} \leq 1.3$ quite dry (ds),
$1.3<\mathrm{K} \leq 1.6$ optimal (o),
$1.6<\mathrm{K} \leq 2.0$ quite wet $(\mathrm{dw})$,
$2.0<\mathrm{K} \leq 2.5$ wet $(\mathrm{w})$,
$2.5<\mathrm{K} \leq 3.0$ very wet (bw),
$\mathrm{K}>3.0$ extremely wet (sw).

The values of Selianinov's hydrothermal coefficient $(\mathrm{K})$ are presented in Table 2. It was assumed that extreme conditions took place when its value was below 0.7 and above 2.5 (Skowera and Puła, 2004). The year 2016 was characterized by a lack of a period with optimal conditions for plant growth. A high level of precipitation in July $(\mathrm{K}=2.15)$ and drought in most of the remaining months hindered proper growth and development of plants.

\section{RESULTS AND DISCUSSION}

\section{Floristic composition of the meadows}

The floristic diversity of the meadows was quite rich. The plants included 14 species of grasses (Table 3), 4 species of Fabaceae (Table 4), and 17 species of herbs and weeds (Table 5). The number of all plant species in the meadows was also diverse and ranged from 16 in unit 1 to 31 in unit 6 . The greatest number of grass species of 10 was in unit 4, with 9 species in units 3 and 6. In meadows 2 , 1 , and 5 there were 7,6 , and 5 species of grass, respectively. Qualitatively, the Forage Value Index (FVI) proposed by Filipek (1973) and ranging from 10, as the highest value, to -3 , the lowest was used as a rating system. The vegetation on unit 1 had the highest value, with the FVI of 9.17, while the FVI value of unit 3 forage was the lowest and equalled 8.44. The follow-

Table 1. Average air temperature $\left({ }^{\circ} \mathrm{C}\right)$ and precipitation $(\mathrm{mm})$ in the growing season

\begin{tabular}{|c|c|c|c|c|c|c|c|c|}
\hline \multirow{3}{*}{ Year } & \multicolumn{8}{|c|}{ Month } \\
\hline & Apr. & May & June & July & Aug. & Sept. & Oct. & Mean \\
\hline & \multicolumn{8}{|c|}{ Temperature $\left({ }^{\circ} \mathrm{C}\right)$} \\
\hline 2016 & 8.9 & 14.6 & 18.1 & 19.0 & 17.9 & 14.4 & 6.8 & 14.2 \\
\hline $\begin{array}{l}\text { Long-term } \\
\text { average }\end{array}$ & 8.5 & 14.0 & 17.4 & 19.8 & 18.9 & 13.2 & 7.9 & 14.2 \\
\hline \multicolumn{9}{|c|}{ Precipitation (mm) } \\
\hline 2016 & 50.2 & 35.5 & 55.6 & 126.8 & 58.2 & 15.4 & 161.2 & 71.8 \\
\hline $\begin{array}{l}\text { Long-term } \\
\text { average }\end{array}$ & 33.0 & 52.0 & 52.0 & 65.0 & 56.0 & 48.0 & 28.0 & 47.7 \\
\hline
\end{tabular}


Table 2. Selianinov's hydrothermal coefficient $(\mathrm{K})$ during the growing season

\begin{tabular}{|c|c|c|c|c|c|c|c|}
\hline \multirow{2}{*}{ Year } & \multicolumn{7}{|c|}{ Months } \\
\cline { 2 - 8 } & $\mathrm{IV}$ & $\mathrm{V}$ & $\mathrm{VI}$ & $\mathrm{VII}$ & $\mathrm{VIII}$ & $\mathrm{IX}$ & $\mathrm{X}$ \\
\hline \multirow{2}{*}{2016} & 1.89 & 0.82 & 1.02 & 2.15 & 1.05 & 0.36 & 7.65 \\
& $(\mathrm{dw})$ & $(\mathrm{s})$ & $(\mathrm{ds})$ & $(\mathrm{w})$ & $(\mathrm{ds})$ & $(\mathrm{ss})$ & $(\mathrm{sw})$ \\
\hline
\end{tabular}

Table 3. FVI values of Poaceae species in individual meadows

\begin{tabular}{|c|c|c|}
\hline Plant species & FVI values & $\begin{array}{c}\text { Meadows } \\
\text { number }\end{array}$ \\
\hline Festuca pratensis & 10 & $1,2,3,4,5,6$ \\
\hline Poa pratensis & 10 & $1,2,3,4,6$ \\
\hline Phleum pratense & 10 & $1,2,3,4,5,6$ \\
\hline Lolium perenne & 10 & $1,2,3,4,5,6$ \\
\hline Dactylis glomerata & 9 & $1,2,3,4,5,6$ \\
\hline Alopecurus pratensis & 9 & 6 \\
\hline Agrostis alba & 9 & $3,4,6$ \\
\hline Lolium multiflorum & 9 & 4 \\
\hline Poa trivialis & 8 & 4 \\
\hline Agropyron repens & 7 & $2,4,6$ \\
\hline Agropyron intermedium & 7 & 6 \\
\hline Festuca rubra & 6 & $1,2,3,4$ \\
\hline Festuca arundinacea & 6 & 3 \\
\hline Poa annua & 6 & 3,5 \\
\hline
\end{tabular}

FVI - Forage Value Index

Table 4. FVI values of Fabaceae species in individual meadows

\begin{tabular}{|c|c|c|}
\hline Plant species & FVI values & $\begin{array}{c}\text { Meadows } \\
\text { number }\end{array}$ \\
\hline Medicago sativa & 10 & $2,3,5,6$ \\
\hline Trifolium repens & 10 & $1,2,3,4,5,6$ \\
\hline Trifolium pratense & 9 & $1,2,6$ \\
\hline Trifolium hybridum & 9 & 5 \\
\hline
\end{tabular}

FVI - Forage Value Index

ing relationship was observed: the more common species of grass appeared spontaneously in the meadows, the more the quality of the vegetation decreased. Grass species dominated in the meadows, displacing other plants. However, the forage of the highest value was produced on those meadows where the species of grass had been sown as a mixture. Those meadows were free of other invasive grass species and with a small number of weeds and herbs, of which the largest part were such plants as Plantago lanceolata $(\mathrm{FVI}=7)$, Taraxacum officinale (FVI $=6$ ), and Achillea millefolium $(\mathrm{FVI}=6)$. The grass species with the highest FVI value of 10, such as Festuca pratensis, Phleum pretense, Lolium perenne, and Poa pratensis were present on all the meadows, with the exception of unit 5 where Poa pratensis was not found. Dactylis glomerata, with the FVI of 9, were also found in all units. Another grass, very common, but mostly due to natural regeneration, was Festuca rubra (FVI $=6)$, found in meadows 1, 2, 3, and 4. Agrostis alba $(\mathrm{FVI}=9)$ was observed in three units: 3, 4, and 6. In turn, Agropyron repens $(\mathrm{FVI}=7)$ was also in three meadows. Both of these species were self-sown. Poa annua, with the FVI of 6 , was recorded in units 3 and 5 . It is grass with a high content of soluble sugars and carotene, so it has a large forage value. However, it is not used in meadow mixtures because of its low yield. Other grass species were found as single specimens. Other studies found similar species arrangements (Moraczewski, 1996; Kulik and Baryła, 2013). Kamiński (2000) reported large expansiveness of Poa pratensis on peat-muck soil when vegetation seasons were less favourable for Lolium perenne; a similar relationship was also observed in the present experiment. Czyż et al. (2013) emphasized the high prevalence of Poa pratensis in organic and organomineral soil in Polish West Pomerania. Using full cultivation to regenerate grassland on peat-muck soil, Gos et al. (1998) created a meadow with a predominant participation of Dactylis glomerata and Phleum pretense, with a high usefulness of these species for meadow regeneration on organic soil. Regenerating grassland also on organic soil, as reported by Baryła and Kulik (2006), took advantage of high durability of Dactylis glomerata and Phleum pretense in meadow vegetation.

The Fabaceae plants were in all units, with their FVI value of 10 and 9, depending on the species. It largely affected the quality of the vegetation and the quality of the forage. Trifolium repens $(\mathrm{FVI}=10)$ constituted the lower layer of the vegetation in each unit. Red clover $(\mathrm{FVI}=9)$ was in units 1,2, and 6, while Trifolium hybri$\operatorname{dum}(\mathrm{FVI}=9)$ was only found in unit 5. However, of all the plants of the Fabaceae family alfalfa was the most resistant to the drought stress and had the highest yield. Its roots grow very deep, even to about $10 \mathrm{~m}$ in the soil profile, piercing the plough pan without a problem, and during the periods of droughts, it uses the water and minerals 
Table 5. FVI values of weed and herb species in individual meadows

\begin{tabular}{|c|c|c|}
\hline Plant species & FVI values & $\begin{array}{c}\text { Meadows } \\
\text { number }\end{array}$ \\
\hline Plantago lanceolata & 7 & 1,5 \\
\hline Taraxacum officinale & 6 & $1,2,3,4,5,6$ \\
\hline Achillea millefolium & 6 & $1,3,4,5$, \\
\hline Dancus carota & 4 & 6 \\
\hline Rumex crispus & 2 & $2,4,5$ \\
\hline Ranunculus repens & 2 & 6 \\
\hline Stellaria media & 2 & $3,4,5$ \\
\hline Leontodon autumnalis & 6 & 5 \\
\hline Veronica arvensis & 2 & 5 \\
\hline Plantago maior & 2 & 3,6 \\
\hline Centaurena cyanus & 3 & 6 \\
\hline Echinochloa crus-galli & 3 & 6 \\
\hline Myosotis arvensis & 1 & 4 \\
\hline Cirsium arvense & 0 & 4 \\
\hline Persicaria masculosa & 1 & 6 \\
\hline Polygonum aviculture & 3 & 6 \\
\hline Euphoria helioskopia & -2 & 6 \\
\hline
\end{tabular}

FVI - Forage Value Index

from deeper soil layers. Even in the year of sowing, it copes with drought stress well. Alfalfa was present in units $2,3,5$, and 6 . It was found in the freshly formed meadow 6 , when grass, herbs, and weeds were dying, but that plant did quite well, with its yield at a satisfactory level.

Herbs and weeds improve the diversity of a meadow, and grassland with no other plants than grasses and Fabaceae may produce forage which is less appetizing or devoid of some of the ingredients that stimulate digestion. Only some species like Achillea millefolium or Plantago lanceolata can be called herbs. The same herbs, with their increased share in the vegetation $(10 \%)$, can become noxious weeds, limiting the growth and development of valuable forage species. Therefore, such a situation is not desirable when a meadow is used as a source of forage.

The most common herb which appeared on all units was Taraxacum officinale. Achillea millefolium observed in units 1, 3, 4, and 5 raises the forage palatability. Plantago lanceolata with the highest FVI value of 7 was present in units 1 and 5. Stellaria media, Rumex crispus and Viola arvensis, were observed in three units. Plantago lanceolate and Plantago major, were in two units. Other weeds: Dancus carota, Ranunculus repens, Leontodon autumnalis, Centaurena cyanus, Echinochloa crus-galli, Myosotis arvensis, Cirsium arvense, Persicaria masculosa, Polygonum avi- culture and Euphoria helioskopia were found as single specimens. The latter two weeds, present in unit 6 , are dangerous for the health of animals because they contain poisonous substances that do not undergo degradation even in the process of silaging. However, their participation in the vegetation was not large.

\section{The weighing method of botanical analysis}

The change of the floristic composition is a result of either the recovery or degradation of meadow vegetation. The structure of meadow communities decides about the production potential and meadow quality (Grzegorczyk, 1993; Trąba, 1994). The Floristic composition of plants on hydrogenic soils, like, for example, peat-muck soil, is characterized by the dynamic succession (Kaminski, 2000). On grassland, especially in the post-bog habitats with extensive use, high grass species disappear first (Baryła, 2004; Baryła and Kulik, 2006; Janicka and Łukoszyk, 2006). Because of that, there is a need to conduct a research looking for a selection of grass species adequate for the meadow mixtures on organic soil.

The weighing analysis carried out on the meadows showed botanical differences between the units, depending on the harvest, and on the share of different botanicals groups (Table 6). The average share of particular plant groups throughout the growing season was as follows: $60.7 \%$ for grass, $25.5 \%$ for Fabaceae, and $10.8 \%$ for herbs and weeds. This shows a fairly good structure of the yield, with a slightly too high share of herbs and weeds. This was affected mainly by the plant composition in unit 4 , where this share was $28.9 \%$. Unfortunately, the reseeding carried out on meadow 4 turned out not to be successful, as it can be seen from the participation of dicotyledonous plants, the share of which, depending on the harvest, ranged from $26 \%$ to $30.8 \%$, with a growing trend. The other meadows exhibited quite the opposite situation, with a trend of dwindling share of herbs and weeds after consecutive harvests. In the last harvest, it ranged from $8.7 \%$ in unit 1 to just $0.5 \%$ in units 5 and 6 . Meadows 1 and 4, where the main plant of Fabaceae was white clover, did not show major differences in yield. The share of Fabaceae ranged from 9.5\% to $11 \%$ in unit 1 , and from $6.7 \%$ to $10 \%$ in meadow 4 . The share of grass in unit 1 ranged from $76.5 \%$ to $80.3 \%$, and in unit 4 from $59.2 \%$ to $65.3 \%$. A much larger diversity was observed in units 2, 3, and 5, where the main plant of Faba- 
Table 6. Weighing analysis of the vegetation

\begin{tabular}{|c|c|c|c|c|}
\hline Meadows number & Cut & Poaceae & Fabaceae & $\begin{array}{c}\text { Weed and } \\
\text { herb species }\end{array}$ \\
\hline \multirow{4}{*}{1} & $\mathrm{I}$ & $76.5 \%$ & $9.5 \%$ & $14 \%$ \\
\hline & II & $79.3 \%$ & $11 \%$ & $9.7 \%$ \\
\hline & III & $80.3 \%$ & $11 \%$ & $8.7 \%$ \\
\hline & Mean & $78.7 \%$ & $10.5 \%$ & $10.8 \%$ \\
\hline \multirow{5}{*}{2} & 1 & $66.2 \%$ & $25.8 \%$ & $8 \%$ \\
\hline & II & $60.2 \%$ & $33.2 \%$ & $6.7 \%$ \\
\hline & III & $67.3 \%$ & $27.7 \%$ & $5 \%$ \\
\hline & IV & $48.7 \%$ & $48.3 \%$ & $3 \%$ \\
\hline & Mean & $60.5 \%$ & $33.7 \%$ & $5.7 \%$ \\
\hline \multirow{5}{*}{3} & I & $61.3 \%$ & $30.3 \%$ & $8.3 \%$ \\
\hline & II & $66.2 \%$ & $28.7 \%$ & $5.18 \%$ \\
\hline & III & $68.3 \%$ & $29 \%$ & $2.67 \%$ \\
\hline & IV & $24.8 \%$ & $73.7 \%$ & $1.5 \%$ \\
\hline & Mean & $55.2 \%$ & $40.4 \%$ & $4.41 \%$ \\
\hline \multirow{4}{*}{4} & 1 & $65.3 \%$ & $6.7 \%$ & $26 \%$ \\
\hline & II & $59.2 \%$ & $10 \%$ & $30.8 \%$ \\
\hline & III & $62.3 \%$ & $8.7 \%$ & $29 \%$ \\
\hline & Mean & $62.3 \%$ & $8.78 \%$ & $28.9 \%$ \\
\hline \multirow{5}{*}{5} & I & $61.7 \%$ & $28.3 \%$ & $10 \%$ \\
\hline & II & $64.8 \%$ & $29.7 \%$ & $5.5 \%$ \\
\hline & III & $71.7 \%$ & $23.7 \%$ & $4.68 \%$ \\
\hline & IV & $30.2 \%$ & $69.34 \%$ & $0.5 \%$ \\
\hline & Mean & $57.1 \%$ & $37.7 \%$ & $5.17 \%$ \\
\hline \multirow{4}{*}{6} & I & $60 \%$ & $18.7 \%$ & $21.3 \%$ \\
\hline & II & $57.7 \%$ & $35 \%$ & $7.34 \%$ \\
\hline & III & $33.8 \%$ & $65.7 \%$ & $0.5 \%$ \\
\hline & Mean & $50.5 \%$ & $39.8 \%$ & $9.73 \%$ \\
\hline \multicolumn{2}{|c|}{ The mean of the harvests } & $60.7 \%$ & $25.5 \%$ & $10.8 \%$ \\
\hline
\end{tabular}

ceae was alfalfa. In the first (21.05.2016), second (21.06.2016) and third harvest (16.08.2016), the fluctuations in the grass share were small, and it changed approximately by 7 to $10 \%$ and from 2 to $8 \%$ for the Fabaceae plants. The initial share of plants in the meadows was $60-80 \%$ of grass and up to $20 \%$ of Fabacea plants, but it changed in the fourth harvest (29.09.2016), because the ratio was almost opposite. For the grass, it ranged from $24.8 \%$ in unit 3 to $48.7 \%$ in unit 2 , and for Fabaceae from $48.34 \%$ in unit 2 to $73.7 \%$ in unit 3. Similar values to the ones for the unit 3 were reported for unit 5 . In meadow 6 , when it was planted again after the first harvest, there was the fairly high share of herbs and weeds of $21.3 \%$, a favourable participation of Fabaceae plants $(18.7 \%)$, and the share of grass amounting to $60 \%$. In the next harvest, a radical but beneficial fall of the herb and weed share to the level of $7.3 \%$ was observed, together with a large increase of Fabaceae, the share of which was 35\%, and with just a $57.7 \%$ share of grass.

The last harvest showed a total change of the ratio, just like in other units, and it amounted to
$65.7 \%$ for Fabaceae and $33.8 \%$ for grasses, while herbs and weeds, with their participation of $0.5 \%$, almost disappeared. Such a significant change of the relation of grass to Fabaceae plants was brought about by the drought in the spring, because of which the renovation of unit 4 by reseeding failed and a mixture sown in unit 6 was also threatened. The herbs and weeds resistant to temporary water shortages developed better, but after subsequent harvests they gave way to grass and Fabaceae. After the dry early spring, there was enough precipitation before the first and second harvests. However, the lack of rainfall in the second half of June and the first half of July caused the vegetation to dry, so the next harvest was as late as after mid-August. The last harvest was not carried out on units 1 and 4, as it was preceded by another period of drought with the drying of almost entire vegetation. Units 2, 3, 5, and 6, with a considerable share of alfalfa, which is highly resistant to drought stress, did quite well. It is true that the participation of grass there drastically decreased but those meadows were in better shape than the plants in units 1 and 4. 


\section{CONCLUSIONS}

The meadows under consideration occupy a total of 19 hectares and are located on good and medium quality soil of classes IIIa, IIIb, and IVa. They comprise brown soil, leached and acidic, consisting of light clay, with a lower layer of heavy clay and black soil proper of very good quality made up of light clay lying on medium clay. The soil of the meadows had a high and very high content of mineral nitrogen and magnesium, low or medium content of phosphorus, and a very low content of potassium. Three of the analyzed meadows were harvested three times, while the others were harvested four times. The results of the weighing analysis of the meadows were very varied, both between the units and between harvests. However, it should be noted that in all units the grass share, as an average of all harvest, was in majority of cases, in the range from $55 \%$ to $62 \%$. The following grass species were found most often: Festuca pratensis, Lolium perenne, Poa pratensis, Phleum pratense and Dactylis glomerata. Among the Fabaceae plants, Medicago sativa, Trifolium pratense and Trifolium repens were dominant and the share of those plants ranged from $10 \%$ to $39 \%$. A growth in intensification increased the share of those plants. Herbs and weeds were more common in the units with a smaller number of harvests, and their average share was about $10 \%$.

\section{Acknowledgements}

The research carried out under the theme No $357 / 13 / \mathrm{S}$ was financed by the science grant of the Ministry of Science and Higher Education.

\section{REFERENCES}

1. Baryła R., 2004. Suitability of Lolium perenne for meadow mixtures in postboggy habitat. Grassland Science in Poland, 7, 9-20.

2. Baryła R., Kulik M. 2006. Persistence and stability of different cultivars of Lolium perenne L. in pasture and meadow sward on peat-muck soils. Acta Scientiarum Polonorum. Agricultura, 5(2), 5-13.

3. Czyż H., Jänicke H., Kitczak T., Bury M. 2015. The evaluation of grasslands restored with full cultivation method and located on organic soil in the valley of the river Randow (Germany), Grassland Science in Poland, 18, 59-74

4. Czyż H., Kitczak T., Bury M., 2013. The characteristics of coastal grassland in West Pomerania. Plant
Diversity and Evolution, 130, 229-237.

5. Filipek,J. 1973. The proposal for the classification of meadow and pasture plants on the basis of fodder value scores. Progress Agricultural Sciences, 4, 58-69. (in Polish)

6. Goliński P. 1999. Quantitative and qualitative changes in sward of meadows as result of their renovation by method of conventional tillage caused by different seed rate. Grassland Science in Poland, 2, 41-50.

7. Gos A., Kitczak T., Czyż H., Trzaskoś M. 1998. The possibility of improvement of permanent meadow being the base of drying houses by the method of oversowing. Grassland Science in Poland, 1, 133-138.

8. Grzegorczyk S. 1993. Biomass productivity of Phalaris arundinacea and Alopecurus pratensis mixtures in the Łyna River Valley near Olsztyn. Zeszyty Problemowe Postępów Nauk Rolniczych, 412, 115-120. (In Polish)

9. Janicka M. Łukoszyk J. 2006. Improvement of species composition of meadow sward with different share of Deschampsia caespitosa by direct drilling method. Grassland Science in Poland, 9, 67-78.

10. Jankowski K., Ciepiela G.A., Jodełka J., Kisielińska B. 2005. The changes in botanical composition of fallowed meadow sward under the influence of treated mineral and organical fertilizers (research note). Grassland Science in Poland, 8, 266-262.

11. Kamiński J. 2000. Yields, changes in floristic composition, and nutritional value of four phenologically diverse mixtures on peat-muck soil. IMUZ, 20(4), 23-37. (In Polish)

12. Kulik M., Baryła R. 2013. The relationship of share of Lolium perenne and Trifolium repens in pasture sward on peat-muck soil in long-term use. Grassland Science in Poland, 16, 55-67.

13. Moraczewski R. 1996. Meadows and pastures on an agricultural. Warsaw Agricultural University Warsaw, 220.

14. Nazaruk M. 1995. Economic and nature aspects of meadow and pasture restoration. Annales UMCS, Sectio E, L (suppl.), 185-188. (In Polish)

15. Rychnovska M., Blazkova D. and Hrabe F. 1994. Conservation and development of of floristically diverse grasslands in Central Europe, Proc. Of the 15 th Gen. Meet. of the Europ. Grassl. Fed., Wageningen, 266-277.

16. Skowera B. and Puła J. 2004. Pluviometric extreme conditions in spring season in Poland in the years 1971-2000. Acta Agrophys., 3(1), 171-177.

17. Trąba Cz. 1994. Agricultural characteristics of Poa pratensis and Festuca rubra meadows in the Łabuńka River Valley. In: Recent development of grassland science on the basis of the current state of knowledge. Scientific Conference Warsaw Agricultural University Warsaw, Poland, 27-28 September 1994, 380-389. (In Polish) 